Jarosław Pobereżny *, Elżbieta Wszelaczyńska *, Jarosław Chmielewski **, Damian Gorczyca **, Wojciech Kozera ${ }^{* * *}$, Tomasz Knapowski ${ }^{* * *}$

\title{
Safety of parsley intended for processing depending on the cultivation technology and storage
}

\section{Bezpieczeństwo pietruszki przeznaczonej do przetwórstwa w zależności od technologii kultywacji i przechowywania}

\footnotetext{
* Dr inż. Jarosław Pobereżny, dr inż. Elżbieta Wszelaczyńska - Department of Food Technology, Faculty of Agriculture and Biotechnology, UTP University of Science and Technology in Bydgoszcz, Kordeckiego 20A St., 85-225 Bydgoszcz, Poland, e-mail: poberezny@utp.edu.pl

** Dr Jarosław Chmielewski, dr Damian Gorczyca - Institute of Environmental

Protection-National Research Institute, Krucza 5/11d St., 00-548 Warsaw
}

*** Dr inż. Wojciech Kozera, dr inż. Tomasz Knapowski - Department of Agricultural Chemistry, Faculty of Agriculture and Biotechnology, UTP University of Science and Technology in Bydgoszcz, Seminaryjna 5 St., 85326 Bydgoszcz, Poland, e-mail: knap@utp.edu.pl ,kozera@utp.edu.pl

Keywords: ADI, nitrates, cultivation, norms, parsley, storage, consumption

Słowa kluczowe: ADI, azotany, uprawa, normy, pietruszka, przechowywanie, spożycie

\section{Abstract}

The factors that affect the value of parsley for consumption include its taste, flavour and dietary utility (vitamins $\mathrm{C}$ and $\mathrm{E}, \beta$-carotene, potassium, calcium, phosphorus and iron, raw fibre, proteins) as well as the content of hazardous substances, especially nitrogen compounds. A study was carried out in 2013-2015 to determine the effect of the cultivation technology and storage on the safety of parsley intended for processing. The study material was taken from an experiment where the following fertilisers were applied to the ground: nitrogen $\left(0,40,80,120 \mathrm{~kg} \mathrm{~N} \cdot \mathrm{ha}^{-1}\right)$ and magnesium $\left(0 ; 30 \mathrm{~kg} \mathrm{Mg} \cdot \mathrm{ha}^{-1}\right)$. Parsley roots were stored for six months in a storage room at $+1{ }^{\circ} \mathrm{C}$ and $\mathrm{RH} 95 \%$. The content of nitrates (V) and (III) was determined by the ion selective method immediately after the harvest and after storage in parsley roots.

The highest levels of nitrates (V) and (III) were found in parsley roots in the cultivation option where nitrogen for fertilisation was applied at the greatest amount, i.e. $120 \mathrm{~kg} \mathrm{~N} \mathrm{ha}^{-1}$ and magnesium at $30 \mathrm{~kg} \mathrm{Mg} \cdot \mathrm{ha}^{-1}$. Regardless of the measures applied during the vegetation period, prolonged storage of parsley resulted in a decreased content of nitrates (V) and (III) in its roots. The limit for nitrogen content and the acceptable daily intake (ADI) for nitrates $(1.0 \%)$ and nitrites $(4.5 \%)$ were not exceeded in the cultivar under study.

๑) IOŚ-PIB

\section{INTRODUCTION}

Garden parsley (Petroselinum crispum) is one of the major vegetables grown in regions having a moderate climate [Osińska et al. 2012, Włodarek et al. 2013]. The factors that affect the utility of parsley for consumption include its taste, flavour and dietary value (vitamins $\mathrm{C}$ and $\mathrm{E}, \beta$-carotene, potassium, calcium, phosphorus and iron, raw fibre, proteins) as well as the content of hazardous substances, especially nitrogen compounds [Błażewicz-Woźniak, Mitura 2004, Buchter-Weisbrodt 2005, Kołota 2011, Włodarek et al. 2013]. Vegetables and their products are the main source of nitrogen compounds in human nutrition. They supply over $80 \%$ of the nitrite(V) in the daily food ration [Gajewski et al. 2009, Dinev, Mitova 2014, Wszelaczyńska et al. 2014]. Due to their

\section{Streszczenie}

O wartości konsumpcyjnej pietruszki decydują walory smakowe i dietetyczne (witaminy C i E, $\beta$-karoten, potas, wapń, fosfor i żelazo, włókno surowe, białka) oraz zawartość związków szkodliwych, głównie azotowych. W latach 2013-2015 podjęto badania, których celem było określenie wpływu technologii kultywacji i przechowywania na bezpieczeństwo korzeni spichrzowych pietruszki przeznaczonej do przetwórstwa. Materiał badawczy pochodził z doświadczenia gdzie stosowano doglebowo: azot $\left(0,40,80,120 \mathrm{~kg} \mathrm{~N} \cdot \mathrm{ha}^{-1}\right)$ oraz magnez $(0,30$ $\left.\mathrm{kg} \mathrm{Mg} \cdot \mathrm{ha}^{-1}\right)$. Korzenie pietruszki przechowywano w komorze przechowalniczej w temperaturze powietrza $+1^{\circ} \mathrm{C}$ i RH $95 \%$ przez 6 miesięcy. Bezpośrednio po zbiorze i po przechowywaniu w korzeniach pietruszki oznaczono zawartość azotanów(V) i (III) metodą jonoselektywną.

Najwięcej azotanów(V) i (III) gromadziły korzenie pietruszki pochodzące z kultywacji gdzie stosowano nawożenie azotem w najwyższej ilości tj. $120 \mathrm{~kg} \mathrm{~N} \cdot \mathrm{ha}^{-1}$ i magnezem - $30 \mathrm{~kg} \mathrm{Mg} \cdot \mathrm{ha}^{-1}$. Niezależnie od stosowanych w okresie wegetacji czynników długotrwały okres składowania pietruszki spowodował obniżenie zawartości azotanów(V) i (III) w jej korzeniach. W badanej odmianie nie została przekroczona norma zawartości azotanów oraz dzienne dopuszczalne spożycie (ADI) wynoszące 1,0\% (azotany) i 4,5\% (azotyny).

hazardous effect on consumer health, the current studies focus on acute toxicity, which is associated with the development of methemoglobinemia [Tietze et al. 2007, Murawa et al. 2008, Boskovic-Rakocevic et al. 2012]. Large amounts of nitrate(V) are accumulated mainly as a result of improper mineral fertilisation; this applies especially to nitrogen [Śledź, Witrowa-Rajchert 2012]. The production of good-quality parsley roots for immediate consumption and storage can be achieved by cultivating them on an appropriate site and by proper agro-technical measures. Consumers expect vegetables of good quality regardless of the season in which they buy them, so it is important to maintain the right conditions of storage [Pobereżny et al. 2012, Złotek, 
Wójcik 2012, Włodarek et al. 2013, Wszelaczyńska et al. 2014]. During the storage period of unprocessed parsley and other root vegetables, a number of chemical and biochemical processes take place, which can reduce their quality by increasing the content of hazardous compounds [Pobereżny et al. 2012, Wszelaczyńska et al. 2014].

According to the current standards for food in Poland, the level of nitrate(V) in parsley root cannot exceed $400 \mathrm{mg} \cdot \mathrm{kg}^{-1}$ of fresh matter [Murawa et al. 2008].

Considering this stipulation, a study was conducted to check the safety of parsley root in terms of nitrate(V) and (III) contents, immediately after harvest and after long-term storage under controlled conditions.

\section{MATERIALS AND METHODS}

A late cultivar - Halblange Berliner - of root parsley (Petroselinum crispum var. tuberosum) was taken as the study material. The parsley was taken from the field experiment carried out at the Research Station in Wierzchucinek (2013-2015) owned by the Faculty of Agriculture and Biotechnology of the University of Technology and Life Sciences in Bydgoszcz (in KujawskoPomorskie province). The field experiment was carried out on light, slightly acidic soil, with a low level of available $\mathrm{P}$ and $\mathrm{K}$ and a medium level of available $\mathrm{Mg}$. The experiment was set up in a dependent arrangement in three replicates.

Various amounts of nitrogen $\left(0,40,80,120 \mathrm{~kg} \mathrm{~N} \cdot \mathrm{ha}^{-1}\right.$ as ammonium nitrogen - 34\%) and magnesium (0, $30 \mathrm{~kg} \mathrm{Mg} \cdot \mathrm{ha}^{-1}$ as magnesium sulphate $-16 \%$ ) were added to the soil against a constant level of phosphorus (45 kg P.ha-1) and potassium (125 kg K·ha-1) fertilisation. Before sowing, seeds were dressed with Funaben $T$ seed dressing, and cultivation and plant protection measures were applied in accordance with the relevant requirements. Weed control was performed by both plant protection products and manually. The harvest was done during the full maturity phase (between 1 and 10 October). The averaged samples of roots were taken for laboratory and storage study from each plot. Healthy, properly shaped parsley roots were stored for
6 months in a storage room under controlled conditions, i.e. at a temperature of $+1^{\circ} \mathrm{C}$ and $\mathrm{RH} 95 \%$.

Samples taken immediately after harvest and after the full period of storage were analysed in a laboratory; the analyses included nitrate $(\mathrm{V})$ assay by an ion selective method with an Elmetron CX-721 apparatus [Baker, Thompson 1992]. The level of $\mathrm{NO}_{2}^{-}$ ions was determined after their oxidation to $\mathrm{NO}_{3}{ }^{-}$, in a previously prepared extract sample, by the method mentioned above.

The results of a three-year study were analysed statistically by means of the analysis of variance, with Tukey's test to evaluate the significance of differences; the coefficients of variance were determined in order to present the stability of the features under study. Moreover, the daily intake of nitrate(V) and (III) was determined, assuming that $14 \mathrm{~g}$ of storage roots of parsley is consumed. These data were compared with the standards for the highest acceptable daily intake (ADI).

\section{RESULTS AND DISCUSSION}

The content of nitrates (V) and (III) in the parsley storage roots under study following harvest was 156.0 and $13.6 \mathrm{mg} \cdot \mathrm{kg}^{-1}$ of fresh matter, respectively, regardless of the experiment setup (Table 1)

A much lower level of nitrate(V) was achieved in the study by Błażewicz-Woźniak and Mitura [2004] for the traditional and nonconventional (with supplementary crops) cultivation -60 and $42.5 \mathrm{mg} \cdot \mathrm{kg}^{-1}$ of fresh matter, respectively. Pokluda (2006) included 15 cultivars in his study and achieved levels ranging from 113 to $617 \mathrm{mg} \cdot \mathrm{kg}^{-1}$ of fresh matter. Such diverse levels achieved by Pokluda (2006) may result from the time of evaluation, which was confirmed in a study carried out by Gajewski et al. [2009]. Grudzińska and Zgórska [2005] and Tietze et al. [2007] found the level of nitrate(V) in parsley to be 300.0 and $499.2 \mathrm{mg}^{\cdot \mathrm{kg}^{-1}}$ of fresh matter. On the other hand, Tamme et al. [2006] and Murawa et al. [2008] found the average nitrate(V) content to be 966 and $474 \mathrm{mg} \cdot \mathrm{kg}^{-1}$ of fresh matter, respectively, with levels ranging from 674 to 1,588 in the Tamme et al. [2006] study and 54.5 to $1,146.0 \mathrm{mg} \cdot \mathrm{kg}^{-1}$ of fresh matter in the Murawa et al. [2008] study.

Table 1. Content of nitrates (V) and (III) in parsley roots and the coefficients of variation CV [\%] depending on nitrogen and magnesium fertilisation $\left[\mathrm{mg} \cdot \mathrm{kg}^{-1}\right.$ of fresh weight] - immediately after harvest

\begin{tabular}{|c|c|c|c|c|c|c|c|c|}
\hline \multirow{3}{*}{$\begin{array}{c}\text { Fertilisation } \\
\left(\mathrm{N} \mathrm{kg}^{\left.-\mathrm{ha}^{-1}\right)}\right. \\
\text { [A] }\end{array}$} & \multicolumn{6}{|c|}{$\begin{array}{l}\left.\text { Fertilisation (Mg kg } \cdot \mathbf{h a}^{-1}\right) \\
{[\mathrm{B}]}\end{array}$} & \multicolumn{2}{|c|}{$\begin{array}{l}\text { CV } \\
{[\%]}\end{array}$} \\
\hline & \multicolumn{3}{|c|}{ Nitrates $(\mathbf{V})^{*}$} & \multicolumn{3}{|c|}{ Nitrates $(\mathrm{III})^{* *}$} & \multirow{2}{*}{$\mathrm{NO}_{3}^{-}$} & \multirow{2}{*}{$\mathrm{NO}_{2}$} \\
\hline & 0 & 30 & Mean & 0 & 30 & Mean & & \\
\hline 0 & 105,2 & 113,1 & 109,2 & 10,6 & 11,3 & 11,0 & 4,4 & 3,7 \\
\hline 40 & 125,0 & 136,7 & 130,9 & 12,5 & 13,7 & 13,1 & 5,1 & 4,8 \\
\hline 80 & 157,3 & 167,9 & 162,6 & 13,8 & 14,6 & 14,2 & 3,9 & 3,0 \\
\hline 120 & 215,6 & 226,8 & 221,2 & 15,4 & 16,9 & 16,2 & 2,9 & 5,3 \\
\hline Mean & 150,8 & 161,1 & 156,0 & 13,1 & 14,1 & 13,6 & - & - \\
\hline $\operatorname{LSD}_{a=0.05}^{a}$ & $\begin{aligned} * A & =5,67 \\
A / B & =\text { n.s. }\end{aligned}$ & & $\begin{array}{l}, 75 \\
\text { n.s. }\end{array}$ & $\begin{array}{l}* * \quad A=0 \\
A / B=n . s .\end{array}$ & & & $\begin{array}{l}0,23 \\
=\text { n.s. }\end{array}$ & \\
\hline
\end{tabular}

aLSD, least significant difference.

${ }^{\mathrm{b}}$ n.s., not significant. 
Table 2. Content of nitrates (V) and (III) in parsley roots and the coefficients of variation CV [\%] depending on nitrogen and magnesium fertilisation $\left[\mathrm{mg} \cdot \mathrm{kg}^{-1}\right.$ of fresh weight] - after storage

\begin{tabular}{|c|c|c|c|c|c|c|c|c|c|}
\hline \multirow{3}{*}{$\begin{array}{c}\text { Fertilisation } \\
\left(\mathrm{N} \mathrm{kg}^{-h^{-1}}\right) \\
\text { [A] }\end{array}$} & \multicolumn{7}{|c|}{$\begin{array}{l}\text { Fertilisation }\left(\mathbf{M g ~ k g} \cdot \mathbf{h a}^{-1}\right) \\
{[B]}\end{array}$} & \multicolumn{2}{|c|}{$\begin{array}{l}\text { CV } \\
{[\%]}\end{array}$} \\
\hline & \multicolumn{3}{|c|}{ Nitrates $(\mathbf{V})^{*}$} & \multicolumn{4}{|c|}{ Nitrates (III) ${ }^{* *}$} & \multirow{2}{*}{$\mathrm{NO}_{3}^{-}$} & \multirow{2}{*}{$\mathrm{NO}_{2}^{-}$} \\
\hline & 0 & 30 & Mean & & 0 & 30 & Mean & & \\
\hline 0 & 97,0 & 107,9 & 102,5 & & 9,5 & 10,6 & 10,1 & 5,8 & 6,1 \\
\hline 40 & 117,6 & 128,0 & 122,8 & & 11,5 & 12,2 & 11,9 & 5,1 & 3,4 \\
\hline 80 & 145,1 & 158,1 & 151,6 & & 13,3 & 13,9 & 13,6 & 4,8 & 2,8 \\
\hline 120 & 201,8 & 222,7 & 212,3 & & 14,6 & 16,3 & 15,5 & 5,4 & 6,3 \\
\hline Mean & 140,1 & 154,2 & 147,2 & & 12,2 & 13,3 & 12,8 & - & - \\
\hline$L S D^{\mathrm{a}}{ }_{a=0,05}$ & $\begin{aligned} A & =4.52 \\
A / B & =\text { n.s. }\end{aligned}$ & & $\begin{array}{l}.87 \\
\text { n.s. }\end{array}$ & & $A=0.80$ & & $.86 \mathrm{~B} / \mathrm{A}$ & $=0.15$ & \\
\hline
\end{tabular}

aLSD, least significant difference, ${ }^{\mathrm{b}}$ n.s., no significant.

However, it must be emphasised that Tietze et al. [2007] used a different cultivar in their study than the one used in this one and Tamme et al. [2006] and Murawa et al. [2008] examined parsley roots, of unknown cultivation technology, bought in a retail store. Much lower nitrate(III) levels than in this study were achieved by Murawa et al. [2008]. The level of nitrates(III) in all samples analysed by Murawa et al. [2008] was very low $-0.59 \mathrm{mg} \cdot \mathrm{kg}^{-1}$ of fresh matter. Those authors did not apply nitrogen fertilisers, and the year of study proved to be significant. The nitrate(III) levels in some years were even four times higher than in others, which may have been caused by the fact that parsley was purchased on the market. Moreover, low levels of nitrate(III), not exceeding 0.5 $\mathrm{mg} \cdot \mathrm{kg}^{-1}$ of fresh matter, were obtained by Sus et al. [2006] who monitored the market for root vegetables in Slovenia.

The factors applied in this study modified the levels of nitrates $(\mathrm{V})$ and (III) significantly. Both fertilisation with nitrogen and magnesium significantly increased the level of these undesired compounds (Table 1). Smolen et al. [2010] reported that the application of small amounts of nitrogen to the soil in combination with foliar application of nitrogen and magnesium gives a yield with lower levels of nitrogen compounds. The current study did not confirm this relationship, because the highest levels of nitrates $(\mathrm{V})$ and (III) were accumulated in parsley roots fertilised with the largest amount of nitrogen, i.e. $120 \mathrm{~kg} \mathrm{~N} \mathrm{ha}^{-1}$ and magnesium. A different effect achieved in this study resulted from applying a different form of a nitrogen fertiliser and a different method of its application to the plant than used by those authors. Moreover, magnesium sulphate (applied in this study) facilitates absorption of nitrogen by plants, which was demonstrated by Smoleń et al. [2006]. Hence, high levels of nitrogen compounds in parsley roots were achieved in this study (Tables 1 and 2). Each of the nitrogen doses applied in this study caused a systematic increase in the content of nitrates(V) and (III) (Table 1). These findings are in line with those of the study carried out by Kołota [2011], who increased the amount of nitrogen applied from 40 to $160 \mathrm{~kg} \mathrm{~N} \mathrm{ha}^{-1}$ and achieved an increase in the nitrate(V) level from 294 to $508 \mathrm{mg} \cdot \mathrm{kg}^{-1}$ of fresh matter of parsley. Boskovic-Rakocevic et al. [2012] examined a different root vegetable and their findings were similar. A number of authors have emphasised and confirmed that excessively high amounts of nitrogen fertilisers used in cultivation,

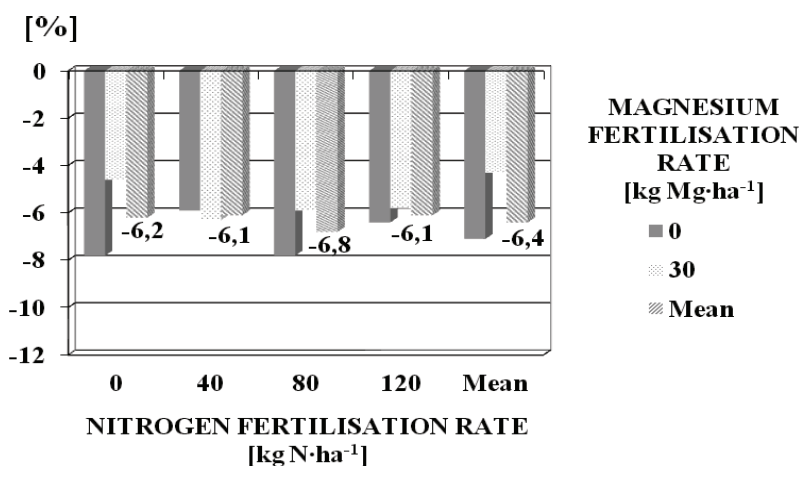

Figure 1. Percentage losses of the content of nitrates $(V)$ in parsley roots depending on nitrogen and magnesium fertilisation

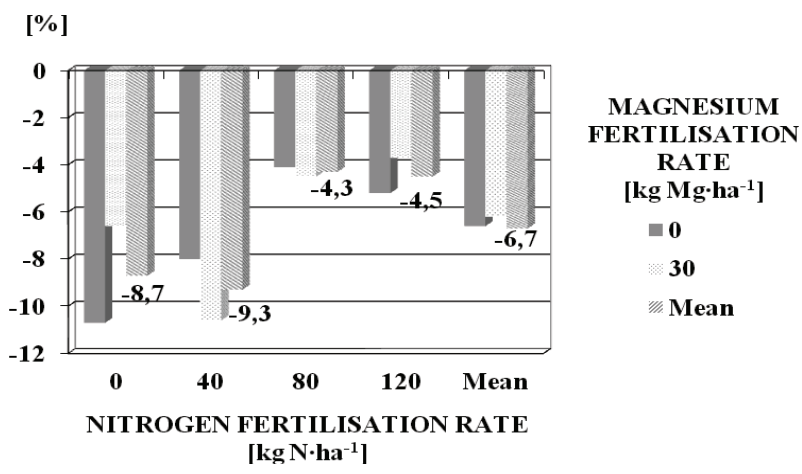

Figure 2. Percentage losses of the content of nitrate(III) in parsley roots depending on nitrogen and magnesium fertilisation

especially when nitrogen is not balanced by other nutrients, result in the accumulation of nitrogen compounds in root vegetables, including harmful nitrate( $\mathrm{V})$ above the acceptable limit [Ekbic et al. 2010, Xia et al. 2011, Boskovic-Rakocevic et al. 2012]. On the other hand, Pasikowska et al. [2002] grew parsley on three different types of soil and they did not record any uniform results of nitrogen fertilisation on nitrate $(\mathrm{V})$ accumulation. Regardless of the measures applied during the vegetation period, the prolonged storage of parsley resulted in a decreased content of nitrates $(\mathrm{V})$ and (III) in its roots (Figs. 1 and 2). 
Table 3. Daily consumption of harmful nutrients while consuming $14 \mathrm{~g}$ of parsley* ${ }^{*} \mathrm{mg} \cdot$ day $\left.^{-1}\right]$.

\begin{tabular}{|c|c|c|c|c|c|c|c|c|c|c|c|c|}
\hline \multirow{3}{*}{ 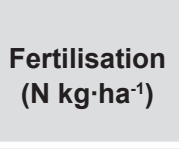 } & \multicolumn{6}{|c|}{ 1. Nitrate(V) } & \multicolumn{6}{|c|}{ 2. Nitrate(III) } \\
\hline & \multicolumn{3}{|c|}{ After harvest } & \multicolumn{3}{|c|}{ After storage } & \multicolumn{3}{|c|}{ After harvest } & \multicolumn{3}{|c|}{ After storage } \\
\hline & $0^{* *}$ & $50^{* *}$ & Mean & 0 & 50 & Mean & 0 & 50 & Mean & 0 & 50 & Mean \\
\hline 0 & 1.47 & 1.58 & 1.53 & 1.36 & 1.51 & 1.43 & 0.15 & 0.16 & 0.15 & 0.13 & 0.15 & 0.14 \\
\hline 40 & 1.75 & 1.91 & 1.83 & 1.65 & 1.79 & 1.72 & 0.18 & 0.19 & 0.18 & 0.16 & 0.17 & 0.17 \\
\hline 80 & 2.20 & 2.35 & 2.28 & 2.03 & 2.21 & 2.12 & 0.19 & 0.20 & 0.20 & 0.19 & 0.19 & 0.19 \\
\hline 120 & 3.02 & 3.17 & 3.10 & 2.82 & 3.12 & 2.97 & 0.22 & 0.24 & 0.23 & 0.20 & 0.23 & 0.22 \\
\hline Mean & 2.11 & 2.26 & 2.18 & 1.96 & 2.16 & 2.06 & 0.18 & 0.20 & 0.19 & 0.17 & 0.19 & 0.18 \\
\hline
\end{tabular}

* - Mean consumption of fresh and processed parsley is $5 \mathrm{~kg} \cdot \mathrm{year}^{-1}$ per person in Poland.

** - Magnesium fertilisation rate $\left[\mathrm{kg} \mathrm{MgO} \cdot \mathrm{ha}^{-1}\right]$

Its content decreased by $6.4 \%$ for nitrate $(\mathrm{V})$ and $6.7 \%$ for nitrate(III). Opinions on the effect of parsley storage on nitrate(V) content in vegetables vary. According to Wrzodak, Elkner [2010], Pobereżny et al. [2012] and Wszelaczyńska et al. [2014], the storage conditions is the main factor affecting vegetable safety in terms of the level of hazardous compounds. Some authors [Ciećko et al. 2010, Wszelaczyńska et al. 2014] have reported that storage results in a considerable increase in the level of nitrates $(\mathrm{V})$ and (III). However, the effect of storage for several months, as studied by Marks [2009], proved to be insignificant. The coefficients of variation for nitrates(V) and (III) (Tables 1 and 2) indicate that the highest variation for nitrates $(\mathrm{V})$ after harvest was achieved following the application of nitrogen at $120 \mathrm{~kg} \cdot \mathrm{ha}^{-1}$ and after storage at $80 \mathrm{~kg} \cdot \mathrm{ha}^{-1}$. On the other hand, the variation for nitrate(III) was the highest when nitrogen was applied at 120 and the lowest was at $80 \mathrm{~kg} \cdot \mathrm{ha}^{-1}$, both after harvest and after storage. This proves that the concentration of nitrates $(\mathrm{V})$ and (III) is affected more by the environmental conditions during its vegetation than by the storage conditions.

An important information for the consumer is provided by Grudzińska and Zgórska [2005], who found that not all types of root vegetable processing reduces the content of nitrate $(\mathrm{V})$. They noted that thermal treatment causes the level of nitrate $(\mathrm{V})$ to drop to $30 \%$ of the initial value.

The FAO/WHO [JECFA 2002] committee for food established the daily intake of nitrates $(\mathrm{V})$ by an adult male to be $0-3.7 \mathrm{mg}$, and that of nitrates (III) to be $0-0.07 \mathrm{mg}$ per $\mathrm{kg}$ of body weight [Burt et al. 1993]. According to different sources, the consumption of vegetables, including parsley, should be about $500 \mathrm{~g}$ in four to

\section{REFERENCES AND LEGAL ACTS}

BAKER W. H., THOMPSON T. L. 1992. Determination of nitrate nitrogen in plant samples by selective ion electrode. Plant Anal. Ref. Proc. for S. US (SCSB \# 368); 23-26.

BŁAŻEWICZ-WOŹNIAK M., MITURA R. 2004. Wpływ uprawy konserwującej na zawartość składników mineralnych w glebie $\mathrm{i}$ w korzeniach pietruszki. Rocz. AR Pozn. 356, Ogrodn. 37: 3-11. BOSKOVIC-RAKOCEVIC L., PAVLOVIC R., ZDRAVKOVIC J., ZDRAVKOVIC M., PAVLOVIC N., DJURI M. 2012. Effect of nitrogen fertilization on carrot quality, Afric. J. Agric Res. 7, 18: 2884-2900. five meals a day. An attempt was made to make a model of daily consumption of nitrates (V) and (III) (Table 3). The consumption of $14 \mathrm{~g}$ of parsley is equivalent to the consumption of $2.1 \mathrm{mg}$ of nitrate(V) and $0.19 \mathrm{mg}$ of nitrate(III) a day, which accounts for $1.0 \%$ and $4.5 \%$ of ADI. Tamme et al. [2006] monitored the Estonian market and determined the daily intake of nitrates with vegetables to be about $58 \mathrm{mg} \mathrm{day}^{-1}$. In this study, the maximum acceptable level was not exceeded.

\section{CONCLUSIONS}

The level of nitrates(V) and (III) depended significantly on the parsley cultivation technology. Fertilisation with nitrogen and magnesium increased the level of nitrates $(\mathrm{V})$ and (III) in parsley storage roots. The storage of parsley caused the level of nitrates(V) and (III) in the roots under study to decrease. The maximum acceptable level of nitrates in fresh matter or the ADI for the parsley cultivar under study was not exceeded.

\section{ACKNOWLEDGMENTS}

The study was carried out using an apparatus bought within the project "Implementation of the second stage of the Regional Centre of Innovation" co-funded by the European Regional Fund as part of the Regional Operational Programme for the Kujawsko-Pomorskie province for the years 2007-2013.

BUCHTER-WEISBRODT H. 2005. Gemüse- Genuss und Gesundheit: Petersilie. Gemüse, 5: 40.

BURT T.P., HEATHWAITE A.L., TRUDGILL S.T. 1993. Nitrate: Process, pattern and management. Chichester, England, Wiley, 10-28.

CIEĆKO Z., ŻOŁNOWSKI A., MIERZEJEWSKA A. 2010. Effect of Foliar Nitrogen and Magnesium Fertilization on the Total, Protein Nitrogen and Nitrates $(\mathrm{V})$ Content in Potato Tubers. Ecol. Chem. Eng. 17, 6: 593-600. 
DINEV N., MITOVA I. 2014. Yield and quality of parsley depend on water quality. Bulg. J. Agric. Sci. 20: 337-341.

EKBIC H.B., OZDEMIR G., SABIR A., TANGOLAR S. 2010. The effects of different nitrogen doses on yield, quality and leaf nitrogen content of some early grape cultivars (V. vinifera L.) grown in greenhouse. Afr. J. Biotechnol. 9, 32: 5108-5112.

GAJEWSKIM., SZYMCZAKP., BAJERM. 2009. The accumulation of chemical compounds in storage roots by carrots of different cultivars during vegetation period. Acta Sci. Pol. Hortorum Cultus 8, 4: 69-78.

GRUDZIŃSKA M., ZGÓRSKA K. 2005. Effect of preliminary and thermal processing on the content of nitrate in vegetables. Rocz. Ochr. Środow., T. 7: 233-241.

JECFA. 2002. Commission Regulation No. 563/2002 of 2 April 2002 amending Regulation (EC) No 466/2001 setting maximum levels for certain contaminants in foodstuffs. FAO/WHO Expert Committee on Food Additives (JECFA). Official Journal of the European Communities L86, 03/04/2002:5-6.

KOŁOTA E. 2011. Yield and quality of leafy parsley as affected by the nitrogen fertilization. Acta Sci. Pol. Hortorum Cultus 10 , 3: 145-154.

MARKS N. 2009. Zawartość azotanów, azotynów i metali ciężkich w bulwach ziemniaka w zależności od długości okresu przechowywania Inż. Rol. 1, 11: 183-187.

MURAWAD, BANASZKIEWICZB., MAJEWSKAE., BŁASZCZUK B., SULIMA J. 2008. Nitrate and nitrite content in selected vegetables and potatoes commercially available in Olsztyn. Bromat. Chem. Toksykol. XLI, 1: 67-71

OSIŃSKA E., ROSŁON W., DRZEWIECKA M. 2012. The evaluation of quality of selected cultivars of parsley (Petroselinum sativum L. ssp. crispum). Acta Sci. Pol., Hortorum Cultus 11, 4: 47-57.

PASIKOWSKA R., DĄBROWSKA B., CAPECKA E., 2002. The effect of nitrogen fertilization rate on the yield and quality of two cultivars of parsley (Petroselinum sativum L. ssp. crispum) grown on different soil types. Folia Hort. 14, 1: 177-185.

POKLUDA R. 2006. An assessment of the nutritional value of vegetables using an ascorbate-nitrate index. Veg. Crops Res. Bull. 64: 28-37

POBEREŻNY J., WSZELACZYŃSKA E., KEUTGEN A. J. 2012. Yield and chemical content of carrot storage roots depending on foliar fertilization with magnesium and duration of storage. J. Elem. 17, 3: 479 - 494
SMOLEŃ S., WOJCIECHOWSKA R., SADY W., SZURAA. 2006. Wpływ formy azotu nawozowego i dokarmiania dolistnego na plon i gospodarkę azotową korzeni spichrzowych marchwi (Daucus Carota L.) Acta Agroph. 7, 3: 721-732.

SMOLEŃ S., SADY W., WIERZBIŃSKAJ. 2010. The effect of plant biostimulation with 'Pentakeep $\mathrm{V}$ ' and nitrogen fertilization on yield, nitrogen metabolism and quality of spinach. Acta Sci. Pol., Hortorum Cultus 9, 1: 25-36

SUS J., KMECL V., GREGORCIC A. 2006. A survey of nitrate and nitrite content of fruit and vegetables grown in Slovenia during 1996-2002. Food Add. and Contam. 23, 4: 385-390.

ŚLEDŹ M., WITROWA-RAJCHERT D. 2012. Chlorophyll and phenolic contents changes during storage of microwaveconvenctive dried parsley leaves. Zesz. Probl. Postęp. Nauk Rol. z. 570: 97-106.

TAMME T., REINIK M., ROASTO M., JUHKAM K., TENNO T., KIIS A. 2006. Nitrates and nitrites in vegetables and vegetablebased products and their intakes by the Estonian population. Food Addit. Contam. 23: 355-361.

TIETZE M., BURGHADT A., BRĄGIEL P., MAC J. 2007. Zawartość związków azotowych w produktach spożywczych. Annales Universitatis Lublin, Vol. XXV (1): 71-77.

WŁODAREK A., BADEŁEK E., ROBAK J. 2013. The influence of various products on storage potential of chinese cabbage (Brassica Pekinensis Rupr.). Zesz. Nauk. Inst. Ogrod., 21: 127-137.

WRZODAK A., ELKNER K. 2010. Jakość sensoryczna marchwi świeżej i przechowywanej z uprawy ekologicznej. Nowości Warzywnicze T50:93-101.

WSZELACZYŃSKA E., POBEREŻNY J., KEUTGEN A. 2014. Effect of genetic conditions, foliar fertilisation with magnesium and storage on the content of nitrates (V) and (III) in the storage roots in carrot. Environmental Protection and Natural Resources, Vol. 25 No 4, 62: 7-11.

XIA L., ZHIWEI S., LEI J., LEI H., ChENGGANG R., MAN W., CHUANGEN L. 2011. High/low nitrogen adapted hybrid of rice cultivars and their physiological responses. Afr. J. Biotechnol. 10, 19: 3731-3738.

ZŁOTEK U., WÓJCIK W. 2012. Effect of coating Parsley Roots (Petroselinum Hortense) with chitosan film on selected characteristics thereof during storage. Żywność. Nauka. Technologia. Jakość, 4, 83: 75 - 85 . 